\title{
Global Journal of Engineering and Technology Advances
}

\section{Off-design performance analysis of gas turbines}

\author{
Ebigenibo Genuine Saturday * and Nweke Promise \\ Department of Mechanical Engineering, University of Port Harcourt, Nigeria.
}

Publication history: Received on 24 July 2020; revised on 31 July 2020; accepted on 03 August 2020

Article DOI: https://doi.org/10.30574/gjeta.2020.4.2.0046

\begin{abstract}
This work deals with the off-design performance analysis of gas turbines. Two gas turbine power stations in Rivers state, Nigeria were used as case studies. Ambient temperature-induced off-design calculations were carried out. This is because no gas turbine operates at its design point in the field and ambient temperature is one of the parameters that changes more frequently in gas turbine operation. Off-design performance models were developed to estimate the power output, thermal efficiency and the exhaust gas temperature at different ambient temperature values. Input data were obtained from the two gas turbine operations and engine adaptation results from previous researches. The power output and the thermal efficiency drops with increase in ambient temperature while the exhaust gas temperature increases with increase in ambient temperature. On the average, power output drops by $1.13 \mathrm{MW}$ when ambient temperature increases by $10 \circ \mathrm{C}$ for the first gas turbine power plant and the value obtained for the second gas turbine power plant which is smaller is 0.473 showing that the power drop is dependent on the power output of the plant. For the same range of ambient temperature increase, thermal efficiency drops by $0.637 \%$ and $0.583 \%$ respectively for the two power plants. Larger drop in power output as well as thermal efficiency occurs at the lower temperature values. The exhaust gas temperature increases with ambient temperature almost uniformly with average value of $1.29 \mathrm{~K}$ and $1.21 \mathrm{~K}$ respectively for $1{ }^{\circ} \mathrm{C}$ increase in ambient temperature. The simulated results closely matched the results obtained from the field at different ambient temperatures. The results of this work will guide power plant operators in economic analysis by estimating the power output beforehand.
\end{abstract}

Keywords: Design point; Gas turbines; Off-design performance; Thermal efficiency

\section{Introduction}

Engine performance parameters such as power output, specific fuel consumption (sfc) and thermal efficiency are provided at the design point of the engine. Engine parameters such as pressure ratio, shaft speed, mass flow rate and the power output are specified usually with the ambient conditions at the design point. Components efficiencies are also given at the design point. Design point performance calculations which usually involves estimating the overall plant efficiency and the air flow rate required to obtain the design power can be easily carried out. The design point of gas turbine specified by engine manufacturers is usually at sea level, ambient temperature and pressure of $15 \circ \mathrm{C}$ and 1 atmosphere respectively and relative humidity of $60 \%$ [1]. In practice, the gas turbine engine operates outside its design conditions (off-design point) occasioned most frequently by the ambient conditions. The estimation of the performance parameters such as the power output at off-design point is crucial since power plants are installed based on the amount of power the unit could produce.

Several methods are employed in off-design performance calculations in gas turbines. These methods include among others components matching, gas path analysis, artificial intelligence based methods, fuzzy logic based methods, Kalman filtering methods, Wittenberg's method and computational fluid dynamics based methods. Components matching method is the most widely used method, and it requires the usage of components characteristics (maps) as in Razak [2] and Saravanamuttoo et al. [3] and the method has been automated. PYTHIA [4] exploits components matching techniques in off-design performance calculations using the code provided by TURBOMACH [5], Cranfield in-house gas

\footnotetext{
* Corresponding author: Ebigenibo Genuine Saturday
} 
turbine performance and diagnostic software. Pathal et al. [6] used the matching technique in carrying out off-design performance characteristics of gas turbines. The effect of variation of fuel consumption on off-design performance of gas turbines has been studied [7].

Off-design performance analysis has been carried out by several researchers [8-12]. Gas turbine characteristics maps are usually used in off-design performance analysis, and some researchers have raised issues concerning the usage of such maps. Carcasci et al. [13] specified that the practical difficulty in using the compressor map as a generalized expression for performance parameters was simply because some are not explicit. Trying to boost the performance forecast precision of gas turbines at different off-design conditions, a non-linear manifold performance acclimation technique was used through genetic algorithm procedure [14]. Off-design performance analysis of gas turbines with emissions as well as the off-design performance analysis of different gas turbine configurations have been investigated [15-17].

The power industry in Nigeria uses a lot of gas turbines and the turbines are bought based on the power output which is at defined operating conditions. In Nigeria, because of the high ambient temperatures experienced in most times of the year, the gas turbine operates in off-design conditions where the power outputs are usually lower than the design point values. Hence off-design performance analysis is necessary to predict the power output in practice and make appropriate payment for gas turbines procured for power production. In this research, temperature-induced off-design performance analysis of gas turbines was carried out exploiting a rapid analytical procedure using two gas turbine power stations in Rivers state, Nigeria as case studies.

\section{Material and methods}

A simplified algorithm for off-design performance calculation is presented here and applied to simple cycle gas turbine cycle with one compressor and one turbine suitable for power production. Figure 1 shows the temperature-entropy (T-s) and block diagrams of the simple cycle plant.
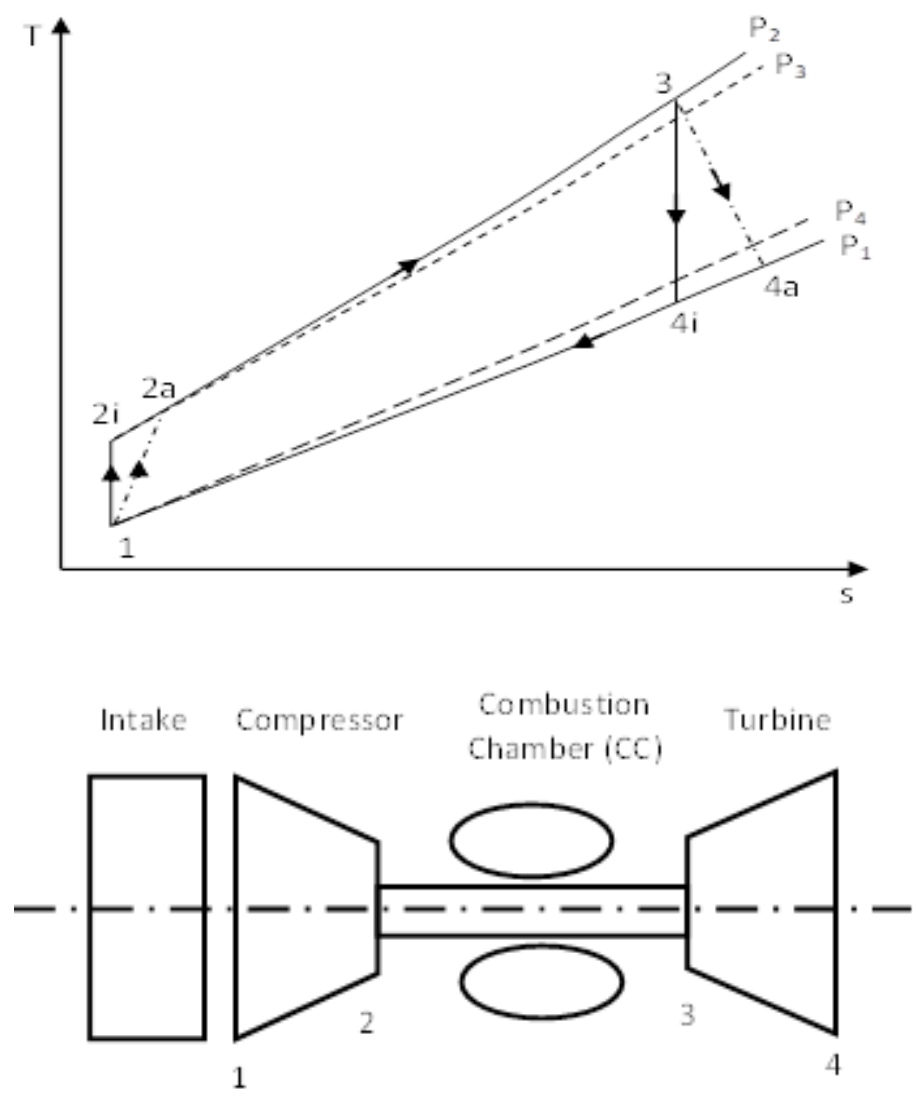

Figure 1 T-s and block diagrams of simple gas turbine engine cycle 
Aside real compression (process 1-2a) and real expansion (process 3-4a), there are pressure losses in the combustion process (process 2a-3) and the expansion process (process $3-4 a$ ). Thus, $\mathrm{p}_{2}$ is less than $\mathrm{p}_{3}$ and $\mathrm{p}_{4}$ is greater than $\mathrm{p}_{1}$. These are viewed as losses in the cycle. The thermodynamic design point performance analysis of the simple cycle plant has been thoroughly investigated using Trans-Amadi power station as a case study [18, 19]. The losses in the various components of the turbine were also estimated. The same procedure was applied to the other power station considered in this work. The off-design performance analysis requires the usage of the design point results hence the design point calculations were first carried out using the methods presented in Saturday and Ofodu [18]

\subsection{Off-design performance analysis}

The performance of engine at any point other than the design point is known as off-design performance. Temperature variation is the only parameter selected for off-design performance of the turbines. The following basic assumptions are made concerning the off-design point:

The pressure ratio across the turbine remains the same for both design point and off-design point of the engine

$$
\left(\frac{P_{3}}{P_{4}}\right)_{D P}=\left(\frac{P_{3}}{P_{4}}\right)_{O D}
$$

$P_{3}$ is the actual pressure at the exit of the combustion chamber while $P_{4}$ is the actual pressure at the exit of the turbine. Subscript DP denotes design point parameter while subscript OD denotes off-design point parameter.

The temperature ratio across the turbine is the same for both design point and off-design point

$$
\left(\frac{T_{3}}{T_{4}}\right)_{D P}=\left(\frac{T_{3}}{T_{4}}\right)_{O D}
$$

$T_{3}$ is the turbine entry temperature (TET) while $T_{4}$ is the actual temperature at the exit of the turbine.

The ratio of the compressor work $W_{C}$ to the turbine work $W_{T}$ is the same for both design point and off-design point

$$
\left(\frac{W_{C}}{W_{T}}\right)_{D P}=\left(\frac{W_{C}}{W_{T}}\right)_{O D}
$$

None dimensional mass flow rate at the entry to the turbine is the same for both design point and off-design point,

$\left(\frac{\dot{m}_{3} \sqrt{T_{3}}}{p_{3}}\right)_{D P}=\left(\frac{\dot{m}_{3} \sqrt{T_{3}}}{p_{3}}\right)_{O D}$

$\dot{m}_{3}$ is the mass flow rate of the working fluid at the entry to the turbine. The work consumed by the compressor is,

$\dot{\mathrm{W}}_{\mathrm{c}}=\dot{\mathrm{m}}_{\mathrm{a}} \mathrm{c}_{\mathrm{pa}}\left(\mathrm{T}_{2 \mathrm{a}}-\mathrm{T}_{1}\right)$

where $\dot{\mathrm{m}}_{\mathrm{a}}$ is the mass flow rate of the working fluid and $\mathrm{c}_{\mathrm{pa}}$ is the specific heat capacity at constant pressure of the working fluid, $\mathrm{T}_{2 \mathrm{a}}$ is the actual temperature at the compressor exit while $\mathrm{T}_{1}$ is the temperature at the inlet to the compressor. The turbine work output is given as,

$\dot{\mathrm{W}}_{\mathrm{t}}=\dot{\mathrm{m}}_{\mathrm{g}} \mathrm{c}_{\mathrm{pg}}\left(\mathrm{T}_{3}-\mathrm{T}_{4 \mathrm{a}}\right)$

where $\dot{\mathrm{m}}_{\mathrm{g}}=\dot{m}_{3}$ is the mass flow rate of the working fluid in the expansion process ( $\dot{\mathrm{m}}_{\mathrm{g}}=\dot{\mathrm{m}}_{\mathrm{a}}+$ $\dot{\mathrm{m}}_{\mathrm{f}} ; \dot{\mathrm{m}}_{\mathrm{f}}$ is fuel flow rate) and $\mathrm{c}_{\mathrm{pg}}$ is the specific heat capacity of the working fluid after combustion has taken place. For the purpose of this analysis, $\dot{\mathrm{m}}_{\mathrm{g}}$ is assumed to be the same as $\dot{\mathrm{m}}_{\mathrm{a}}$ and $\mathrm{c}_{\mathrm{pg}}$ is assumed to be the same as $\mathrm{c}_{\mathrm{pa}}$. The ratio of the compressor work to the turbine work is defined as,

$\beta=\frac{\dot{w}_{c}}{\dot{w}_{t}}$ 
The design point parameters are estimated as in Saturday and Ofodu [18]. As ambient temperature changes, and assuming all other parameters are constant, the off-design parameters are estimated using the basic assumptions highlighted above. From Equations (3), (5), (6) and (7), we obtain the off-design temperature at the turbine exit as,

$\mathrm{T}_{4}^{\mathrm{OD}}=\mathrm{T}_{3}^{\mathrm{OD}}-\frac{\left(\mathrm{T}_{2}^{\mathrm{OD}}-\mathrm{T}_{1}^{\mathrm{OD}}\right)}{\beta}$

where $\mathrm{T}_{4}^{\mathrm{OD}}$ is the exhaust gas temperature for the off-design condition and $\mathrm{T}_{3}^{\mathrm{OD}}$ is the TET at off-design. $\beta$ is estimated at the design point and used in the off-design condition. $\mathrm{T}_{1}^{\mathrm{OD}}$ is the new ambient temperature and it is known. The two unknown temperatures at the off-design point in the cycle at this point are $\mathrm{T}_{2}^{\mathrm{OD}}$ and $\mathrm{T}_{3}^{\mathrm{OD}}$. With the new ambient temperature, the isentropic and the actual temperatures at the compressor exit are presented respectively in Equations (9) and (10),

$T_{2 i}^{O D}=T_{1}^{O D}\left(r_{p}\right)^{\frac{\gamma_{a}-1}{\gamma_{a}}}$

$T_{2}^{O D}=T_{1}^{O D}+\frac{T_{2 i}{ }^{O D}-T_{1}^{O D}}{\eta_{c i}}$

where $r_{p}$ is the pressure ratio of the turbine, $\gamma_{a}$ is the ratio of specific heat capacities of air, $T_{2 i}{ }^{O D}$ is temperature of the working fluid at the compressor exit under isentropic compressor, and $\eta_{c i}$ is the isentropic efficiency of the compression process.

Assuming the fuel flow rate remains constant, $\mathrm{T}_{3}^{\mathrm{OD}}$ is estimated as,

$\mathrm{T}_{3}^{\mathrm{OD}}=\frac{\dot{m}_{a}{ }^{O D} c_{p a} T_{2 a}{ }^{O D^{D}}+m_{f} L C V_{f} \eta_{\mathrm{cc}}}{\left(\dot{m}_{a}{ }^{O D^{+}}+\dot{m}_{f}\right) c_{p f}}$

where $L C V_{f}$ is the lower calorific value of the fuel, $\eta_{\mathrm{cc}}$ is the combustion efficiency obtained as in [18], $c_{p f}$ is the specific heat capacity of the fuel and $\dot{m}_{a}{ }^{O D}$ is the mass flow rate of the working fluid under off-design. $\dot{m}_{a}{ }^{O D}$ is obtained assuming the volume flow rate is constant and expressed as,

$\dot{m}_{a}^{O D}=\dot{m}_{a}^{D P} \times\left(\frac{\mathrm{T}_{1}^{\mathrm{DP}}}{\mathrm{T}_{1}^{O D}}\right)$

$\mathrm{T}_{4}^{\mathrm{OD}}$ can also be obtained by considering equal temperature ratio across the turbine as expressed in Equation (2). With this, $\mathrm{T}_{4}^{\mathrm{OD}}$ is obtained as

$\mathrm{T}_{4}^{\mathrm{OD}}=\mathrm{T}_{3}^{\mathrm{OD}}\left(\frac{\mathrm{T}_{4}}{\mathrm{~T}_{3}}\right)_{D P}$

The difference between the value of $\mathrm{T}_{4}^{\mathrm{OD}}$ obtained from Equations (8) and (13) should be insignificant, otherwise, the air flow rate obtained should be adjusted until the difference becomes insignificant.

Alternatively, the actual air flow rate at off-design can be obtained by balancing the non-dimensional mass flow at the turbine entry. To do this $\mathrm{P}_{2}^{\mathrm{OD}}$ is first estimated from where $\mathrm{P}_{3}^{\mathrm{OD}}$ is calculated assuming same pressure drop in both the design and off-design conditions,

$\mathrm{P}_{2}^{\mathrm{OD}}=\mathrm{P}_{1}\left(\frac{\mathrm{T}_{2 \mathrm{i}}^{\mathrm{OD}}}{\mathrm{T}_{1}^{\mathrm{OD}}}\right)^{\frac{\mathrm{Y}_{\mathrm{a}}}{\mathrm{Y}_{\mathrm{a}}-1}}$

The pressure at the combustor exit under off-design $\mathrm{P}_{3}^{\mathrm{OD}}$ is,

$\mathrm{P}_{3}^{\mathrm{OD}}=\left(1-\frac{\Delta \mathrm{P}_{\mathrm{cc}}}{100}\right) \mathrm{P}_{2}^{\mathrm{OD}}$ 
where $\Delta \mathrm{P}_{\mathrm{cc}}$ is the pressure drop in the combustion chamber. The pressure at the exit of the turbine at off-design $\mathrm{P}_{4}^{\mathrm{OD}}$ is,

$\mathrm{P}_{4}^{\mathrm{OD}}=\mathrm{P}_{3}^{\mathrm{OD}}\left(\frac{P_{4}}{P_{3}}\right)_{D P}$

At the design point, $\mathrm{P}_{3}^{\mathrm{DP}}$ and $\mathrm{P}_{4}^{\mathrm{DP}}$ are given respectively in Equations (17) and (18) as,

$\mathrm{P}_{3}^{\mathrm{DP}}=\left(1-\frac{\Delta \mathrm{P}_{\mathrm{cc}}}{100}\right) \mathrm{P}_{2}^{\mathrm{DP}}$

$\mathrm{P}_{4}^{\mathrm{DP}}=\left(1+\frac{\Delta \mathrm{P}_{\mathrm{EX}}}{100}\right) P_{1}$

where $\Delta \mathrm{P}_{\mathrm{EX}}$ is the percentage loss in pressure in the exhaust process. The mass flow rate of the working fluid at the turbine entry under off-design condition is obtained as,

$\dot{\mathrm{m}}_{\mathrm{g}}^{\mathrm{OD}}=\left(\dot{\mathrm{m}}_{\mathrm{g}} \frac{\sqrt{\mathrm{T}_{3}}}{\mathrm{P}_{3}}\right)_{D P} \times\left(\frac{P_{3}}{\sqrt{T_{3}}}\right)_{O D}$

Since same fuel flow rate was assumed, the air flow rate under off-design is estimated as,

$\dot{m}_{a}^{O D}=\mathrm{m}_{\mathrm{g}}^{\mathrm{OD}}-\dot{\mathrm{m}}_{\mathrm{f}}$

The value of $\dot{m}_{a}{ }^{O D}$ obtained in Equations (12) and (20) are compared and the calculations are carried on if the difference between them is insignificant.

The compressor work input $\dot{\mathrm{W}}_{\mathrm{ca}}{ }^{O D}$, turbine work output $\dot{\mathrm{W}}_{\mathrm{ta}}{ }^{O D}$ and the thermal efficiency $\eta_{\text {th }}{ }^{O D}$ of the plant under offdesign condition are given respectively in Equations (21), (22) and (23),

$\dot{\mathrm{W}}_{\mathrm{ca}}{ }^{O D}=\dot{\mathrm{m}}_{\mathrm{a}}{ }^{O D} \mathrm{c}_{\mathrm{pa}}\left(\mathrm{T}_{2}^{\mathrm{OD}}-\mathrm{T}_{1}\right)$

$\dot{\mathrm{W}}_{\mathrm{ta}}{ }^{O D}=\dot{\mathrm{m}}_{\mathrm{g}}^{\mathrm{OD}} \mathrm{c}_{\mathrm{pg}}\left(\mathrm{T}_{4}^{\mathrm{OD}}-\mathrm{T}_{3}^{\mathrm{OD}}\right)$

$\eta_{\mathrm{th}}{ }^{O D}=\frac{\dot{\mathrm{w}}_{\mathrm{ta}}{ }^{O D}-\dot{\mathrm{W}}_{\mathrm{ca}}{ }^{O D}}{\dot{\mathrm{Q}}_{\mathrm{cc}}{ }^{D}}$

where $\dot{\mathrm{Q}}_{\mathrm{cc}}{ }^{O D}$ is the rate of heat input into the combustion chamber, same as in the design point since same fuel flow rate was assumed. $\dot{\mathrm{Q}}_{\mathrm{cc}}{ }^{O D}$ is given as,

$\dot{\mathrm{Q}}_{\mathrm{cc}}{ }^{O D}=\dot{m}_{f}{ }^{O D} L C V_{f} \eta_{\mathrm{cc}}$

\section{Results and discussion}

Table 1 shows the basic input data used for the analysis in this work while Table 2 shows engine efficiency and loss parameters obtained as presented in [18]. 
Table 1 Input parameters for the analysis

\begin{tabular}{|c|c|c|c|c|}
\hline Items & Symbols & Units & $\begin{array}{l}\text { Values for } \\
\text { power plant I }\end{array}$ & $\begin{array}{l}\text { Values for } \\
\text { power plant II }\end{array}$ \\
\hline Mass flow rate of fuel & $\dot{\mathrm{m}}_{\mathrm{f}}$ & $\mathrm{kg} / \mathrm{s}$ & 3.65 & 1.98 \\
\hline Mass flow of air & $\dot{\mathrm{m}}_{\mathrm{a}}$ & $\mathrm{kg} / \mathrm{s}$ & 247.0 & 124.1 \\
\hline Lower heating values of fuel & $L C V_{f}$ & $\mathrm{MJ} / \mathrm{kg}$ & 48.95 & 41.95 \\
\hline Ambient air temperature & $\mathrm{T}_{0}$ & K & 298 & 298 \\
\hline Ambient air pressure & $\mathrm{P}_{0}$ & $\mathrm{kPa}$ & 101.325 & 101.325 \\
\hline Pressure ratio & $\mathrm{r}_{p}$ & - & 9.67 & 8.6 \\
\hline Isentropic exponent of air & $\Upsilon_{\mathrm{a}}$ & - & 1.4 & 1.4 \\
\hline Isentropic exponent of flue gases & $\Upsilon_{\mathrm{g}}$ & - & 1.33 & 1.33 \\
\hline Power Output & Wnet & $(\mathrm{MW})$ & 65 & 26 \\
\hline
\end{tabular}

Table 2 Engine efficiency and loss parameters

\begin{tabular}{lcclc}
\hline Items & Symbols & Unit & $\begin{array}{c}\text { Values } \\
\text { power plant I }\end{array}$ & $\begin{array}{c}\text { Values } \\
\text { power plant II }\end{array}$ \\
\hline Compressor isentropic efficiency & $\eta_{\mathrm{c}, \mathrm{i}}$ & $\%$ & 88.89 & 84.44 \\
Turbine isentropic efficiency & $\eta_{\mathrm{t}, \mathrm{i}}$ & $\%$ & 92.78 & 91 \\
Combustion efficiency & $\eta_{\mathrm{cc}}$ & $\%$ & 99.5 & 97.83 \\
Combustion Pressure Loss & $\Delta \mathrm{P}_{\mathrm{cc}}$ & $\%$ & 4.67 & 3.33 \\
Exhaust Pressure Loss & $\Delta \mathrm{P}_{\mathrm{ex}}$ & $\%$ & 3.67 & 3.33 \\
\hline
\end{tabular}

The effect of ambient temperature on the net power output and the thermal efficiency is presented in Table 3 for power plant I and in Table 4 for power plant II. The ambient temperature is presented as the value off the design point temperature, where the design point is taken as $25^{\circ} \mathrm{C}(298 \mathrm{~K})$. Ambient temperature off the design point is the difference between the ambient temperature and the design point temperature; 0 in the Tables thus indicating the design point. Both the net power output and the thermal efficiency drops with increase in the ambient temperature. On the average, power output decreases by $1.13 \mathrm{MW}$ when ambient temperature increases by 10 units for power plant I, but the value obtained for power plant II is $0.473 \mathrm{MW}$. For thermal efficiency, it decreases by about $0.637 \%$ when ambient temperature increases by 10 units for power plant I, while the drop in thermal efficiency for power plant II is about $0.583 \%$. The power output and the thermal efficiency drops are higher with power plant I which is a bigger plant. This is expected because the bigger plant will respond to the change in ambient temperature more greatly compared to the smaller plant.

Table 3 Power output and thermal efficiency of power plant I at off-design

\begin{tabular}{lll}
\hline $\begin{array}{l}\text { Ambient temperature off the } \\
\text { design point (目) }\end{array}$ & Net power output (MW) & Thermal efficiency (\%) \\
\hline-10 & 66.20 & 37.24 \\
-5 & 65.54 & 36.87 \\
0 & 65.00 & 36.52 \\
5 & 64.34 & 36.19 \\
10 & 63.8 & 35.89 \\
15 & 63.29 & 35.6 \\
20 & 62.81 & 35.33 \\
\hline
\end{tabular}


Table 4 Power output and thermal efficiency of power plant II at off-design

\begin{tabular}{lll}
\hline $\begin{array}{l}\text { Ambient temperature off } \\
\text { the design point ([C) }\end{array}$ & Net power output (MW) & Thermal efficiency (\%) \\
\hline-10 & 26.72 & 32.88 \\
-5 & 26.44 & 32.54 \\
0 & 26.00 & 32.22 \\
5 & 25.94 & 31.92 \\
10 & 25.71 & 31.64 \\
15 & 25.50 & 31.38 \\
20 & 25.30 & 31.13 \\
\hline
\end{tabular}

One very important parameter in gas turbine operations is the temperature of the exhaust gases to the atmosphere. The higher the exhaust gas temperature for simple open cycle operation, the more danger the plant poses to the environment in terms of pollution. The exhaust gas temperature increases with the ambient air temperature at the compressor inlet and this is shown for power plant I in Figure 2 and for power plant II in Figure 3. The rate of increase of the exhaust gas temperature with increase in ambient temperature is almost uniform with an average value of 1.29 $\mathrm{K}$ for $1{ }^{\circ} \mathrm{C}$ increase in ambient temperature for power plant I, but the value for power plant II is $1.21 \mathrm{~K}$. Here again, the bigger plant responds more to ambient temperature variation.

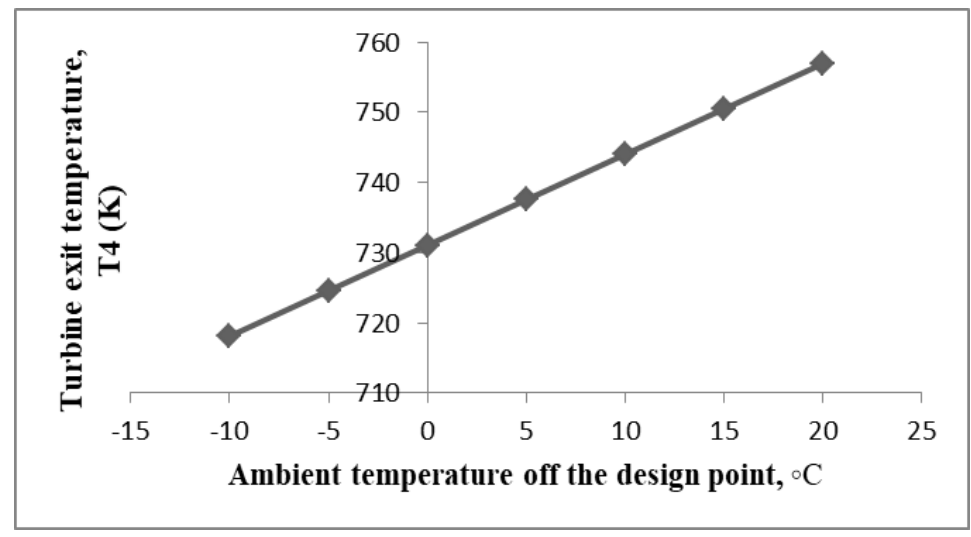

Figure 2 Variation of turbine exit temperature with ambient temperature for power plant I

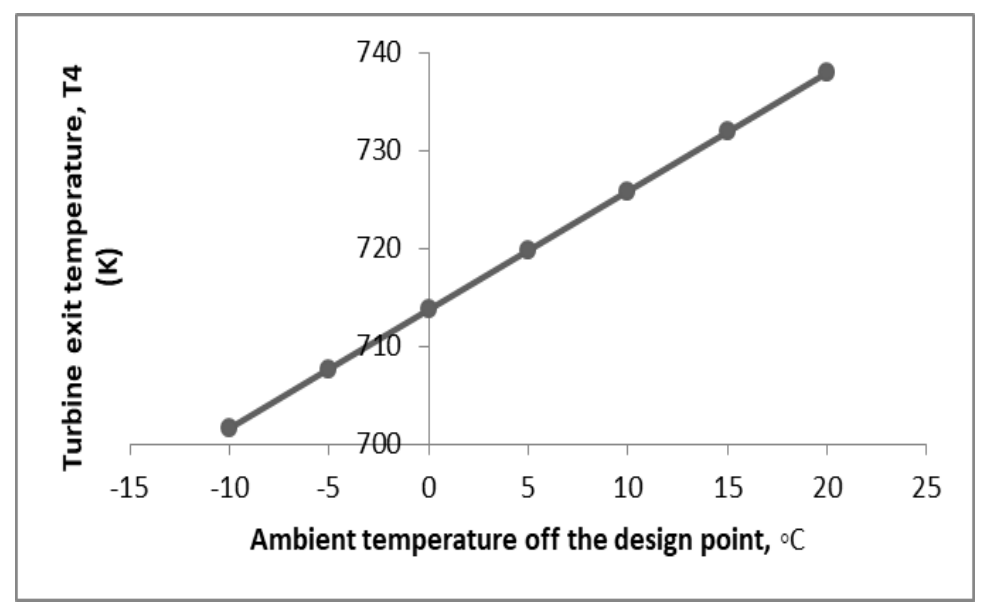

Figure 3 Variation of turbine exit temperature with ambient temperature for power plant II 
Both the power output and the thermal efficiency decreases with increase in the ambient temperature as earlier pointed out, but, the nature of the decrease need to be examined. Higher magnitude of both power output drop and thermal efficiency drop occurs at the lower range of ambient temperatures. That is, when ambient increase occurs at lower temperature levels (say from 290 to $295 \mathrm{~K}$ in this case), the power output and the thermal efficiency drops will be greater than those obtained when ambient temperature increases from $295 \mathrm{~K}$ to $300 \mathrm{~K}$. These occurrences are presented in Figures 4 and 5 for power plants I and II respectively. This is because gas turbine power plants operates better at lower ambient temperatures yielding higher thermal efficiencies and power outputs; hence, ambient temperature variations at lower ambient temperatures leads to greater magnitude variations in power output as well as thermal efficiency.

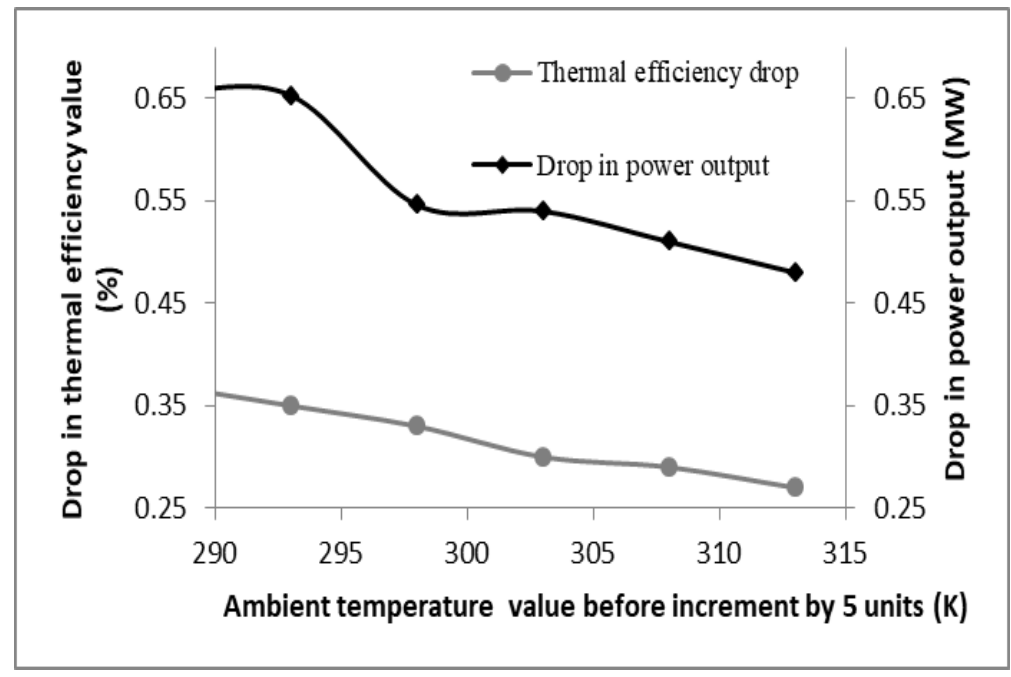

Figure 4 Drop in thermal efficiency and power output with ambient temperature increment for power plant I

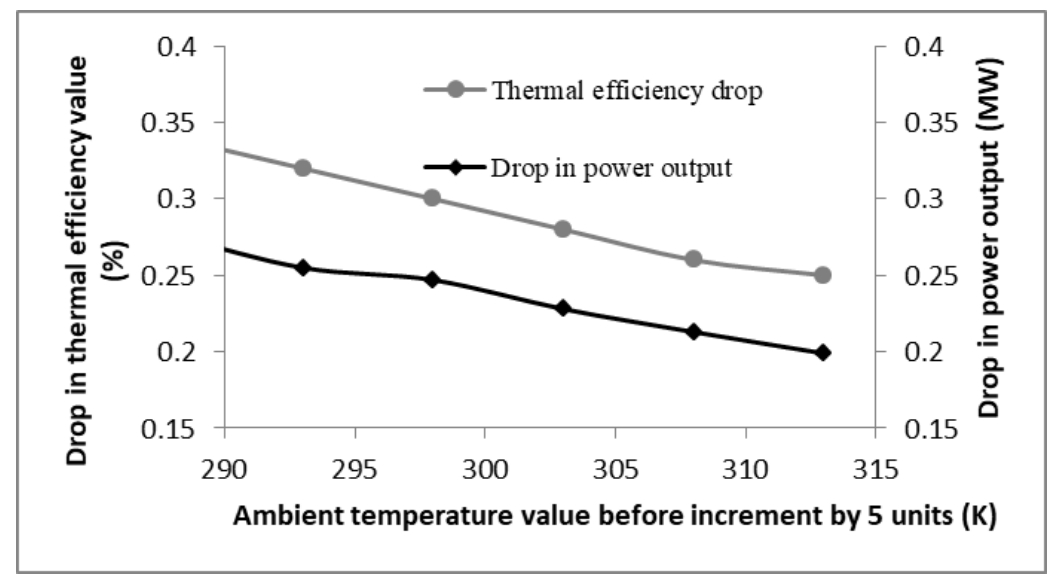

Figure 5 Drop in thermal efficiency and power output with ambient temperature increment for power plant II

To validate the accuracy of the off-design calculations, average field data collected over a period of four months of engine operation were compared with the off-design simulation results at different ambient temperatures. The average power output from the field at different ambient temperatures are compared with the values obtained from the simulations for power plant I and this is presented in Figure 6. The values obtained from the simulations are higher for all the ambient temperatures considered but the values are closer at lower ambient temperatures. The higher simulation values may indicate that the system efficiency values used in the simulations are higher than those of the real engine or the loss parameters are lower than those of the real engine or both. The average percentage difference between the simulated power output and that from the field is $0.38 \%$. The off-design calculations thus predict the engine performance at off-design closely. 


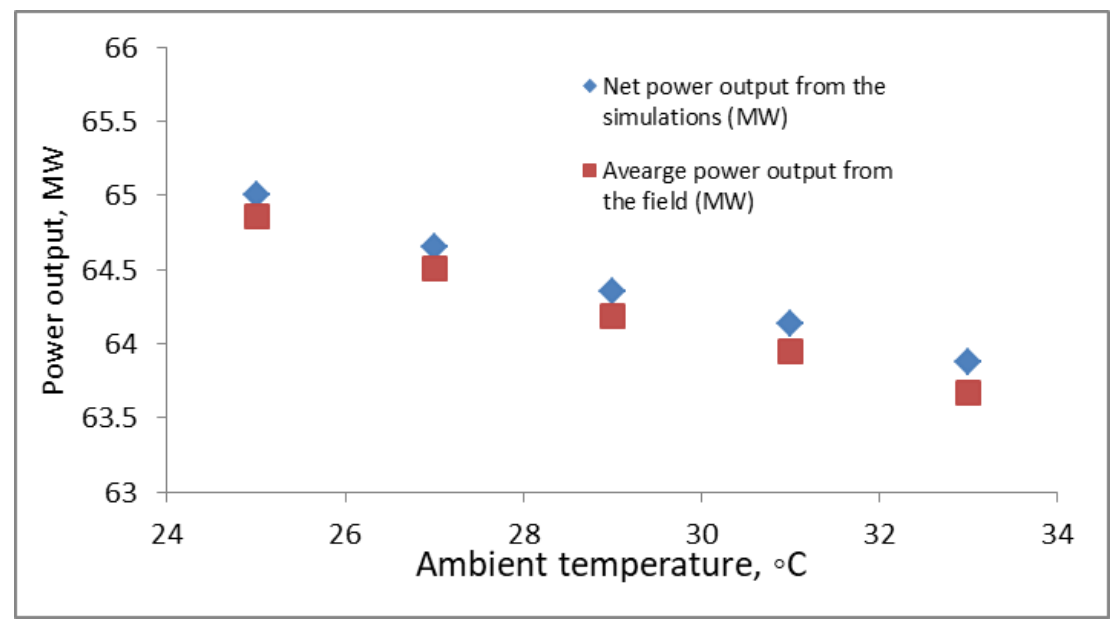

Figure 6 Net power output at different ambient temperatures from the off-design simulations and from the field for power plant I

\section{Conclusion}

Off-design performance analysis of gas turbines was carried out in this work using two gas turbine power stations in Rivers state, Nigeria. Gas turbines have a design point where the pressure ratio, fuel flow rate, air flow rate, power output, ambient temperature and other parameters are specified. In the field, variation of ambient conditions alone will make gas turbines to operate at conditions outside the design conditions. Ambient temperature-induced off-design performance was carried out in this work because of constant variation of ambient temperature within any 24 hours period of gas turbine operations. The power outputs and the thermal efficiencies at different ambient temperatures were estimated. Power output drops with increase in ambient temperature, with greater magnitude of power drop occurring at lower temperatures. An average of $1.13 \mathrm{MW}$ drop in power output for $10 \circ \mathrm{C}$ increase in ambient temperature was obtained in the bigger gas turbine plant while $0.473 \mathrm{MW}$ drop in power output was obtained in the smaller gas turbine plant. This indicates that the amount of power drop with ambient temperature is dependent on the plant and not uniform across all power plants. Thermal efficiency also drops with increase in ambient temperature, and greater drop is observed in the bigger gas turbine plant. The developed off-design calculations produce results that closely matched those from the field.

\section{Compliance with ethical standards}

\section{Acknowledgments}

The authors are grateful to the department of mechanical engineering, university of Port Harcourt for providing good environment for this research.

\section{Disclosure of conflict of interest}

This work was not sponsored by any organization or agency and there is no conflict of interest of any sort from any quarters.

\section{References}

[1] Saturday EG, Li YG, Ogiriki EA and Newby MA. (2017). Creep-life usage analysis and tracking for industrial gas turbines, J. Propuls. Power, 33(5), 1305-1314.

[2] Razak AMY. (2007). Industrial gas turbines: performance and operability. Woodhead Publishing Limited, Boca Raton, Florida, USA, 174-178.

[3] Saravanamuttoo HIH, Rogers GFC, Cohen H and Straznicky PV. (2009). Gas turbine theory, Sixth edition. Pearson Educational Limited, London, UK, 309-315. 
EG Saturday and P Nweke / Global Journal of Engineering and Technology Advances, 2020, 04(02), 001-010

[4] Li YG and Singh R. (2005). An advanced gasturbine gaspath diagnostic system-PYTHIA, Proceedings of the 27th International Symposium on Air Breathing Engines, International Soc. of Air-Breathing Engines Paper ISABE2005-1284.

[5] Macmillan WL. (1974). Development of a modular type computer program for calculation of gas turbine off design performance, Ph.D thesis, Cranfield University, UK.

[6] Pathak M, Suresh KP and Saha UK. (2005). Prediction of off-design performance characteristics of a gas turbine cycle using matching technique. International Journal of Turbo and Jet Engines, 22, 103-119.

[7] Park Y, Park S, Lee J and Choi G. (2014). Effect of variation of fuel composition on gas turbine off-design performance. Applied Mechanics and Materials, 666, 194-198.

[8] Lee JJ, Kang DW and Kim TS. (2011). Development of a gas turbine performance analysis program and its application. Energy Procedia, 36(8), 5274-5285.

[9] Schobeiri T and Abouelkheirf M. (1992). Row-by-row off-design performance calculation method for turbines. Journal of Propulsion and Power, 8(4), 823-828.

[10] Korakianitis $\mathrm{T}$ and Svensson K. (1999). Off-design performance of various gas-turbine cycle and shaft configuration. J. Eng. Gas Turbine Power, 121, 649-655.

[11] Lazzaretto A and Toffolo A. (2001). Analytical and neural network models for gas turbine design and off-design simulation. Int. J. Applied Thermodynamics, 4(4), 173-182.

[12] Gobran MH. (2013). Off-design performance of solar centaur-40 gas turbine engine using simulink. Ain Shams Engineering Journal, 4(2), 285-298.

[13] Carcasci C, Costanzi F and Pacifici B. (2014). Performance analysis in off-design condition in gas turbine airbottoming combined system. Energy Procedia, 45, 1037-1046.

[14] Li YG, Abdul Ghafir MF, Wang L, Singh R, Huang K and Feng X. (2011). Non - linear multiple point gas turbine offdesign performance adaptation using a genetic algorithm. J. Eng. Gas Turbine Power, 133(7), 1-9.

[15] Andreini A and Facchini B. (2004). Gas turbines design and off-design performance analysis with emissions evaluation. Journal of Eingineering for Gas Turbine and Power, 126, 83-91.

[16] Benato A, Stoppato A, Mirandola A and Del Medico M. (2017). Design and off-design analysis of an ORC coupled with a micro-gas turbine. Energy Procedia, 129, 551-558.

[17] Yang C, Huang Z and Ma X. (2017). Comparative study on off-design characteristics of CHP based on GTCC under alternative operating strategy for gas. Energy, 145, 1-9.

[18] Saturday EG and Ofodu JC. (2018). Development and application of gas turbine performance analysis software: part 1- ideal cycles and real cycles. International Journal of Computer Applications, 180(37), 20-26.

[19] Saturday EG, Ofodu JC and Torbira MS. (2018). Development and application of gas turbine performance analysis software: part ii - modified cycles. International Journal of Computer Applications, 179 (54), 6-14.

\section{How to cite this article}

Saturday EG and Nweke P. (2020). Off-design performance analysis of gas turbines. Global Journal of Engineering and Technology Advances, 4(2), 01-10. 